\title{
New US law applies 'sunshine' to physician payments and gifts from drug, device industries
}

Published at www.cmaj.ca on May 19

$\mathrm{T}$ he sun is rising over a shadowed corner of medicine. United States drug and medical device manufacturers are coming under new obligations to disclose billions of dollars in payments and gifts to physicians and researchers.

Whether it's dinner for a doctor, a US\$2000-a-day moonlighting gig or a multi-million dollar research arrangement, these payments are a prime marketing tool for industry and a lucrative source of extra income for physicians.

Legislators decided patients and the larger public have a right to know who is paying for what - and to whom.

The broad health care reforms recently made law by the US Congress and President Barack Obama incorporate "physician payment sunshine" rules that require big drug companies, device makers and biologic firms to report payments and inkind transfers to doctors totalling US\$100 a year or more. Even a \$10 burger counts.

The companies must start collecting the information in 2012, although several have already begun. Starting in 2013, the government will begin releasing a massive database fed to it by industry, packed with a level of detail never before seen.

The law "will result in a great deal of new information about the extent and nature of financial ties between doctors and the pharmaceutical industry," as well as related enterprises, says Allan Coukell, director of the Pew Prescription Project in Boston, Massachusetts, a leading US public policy research group.

Those relationships are threaded through the health care system, he says, citing payments to individual researchers exceeding US\$1 million. "We've had medical device companies that were making cash rebates to physi-

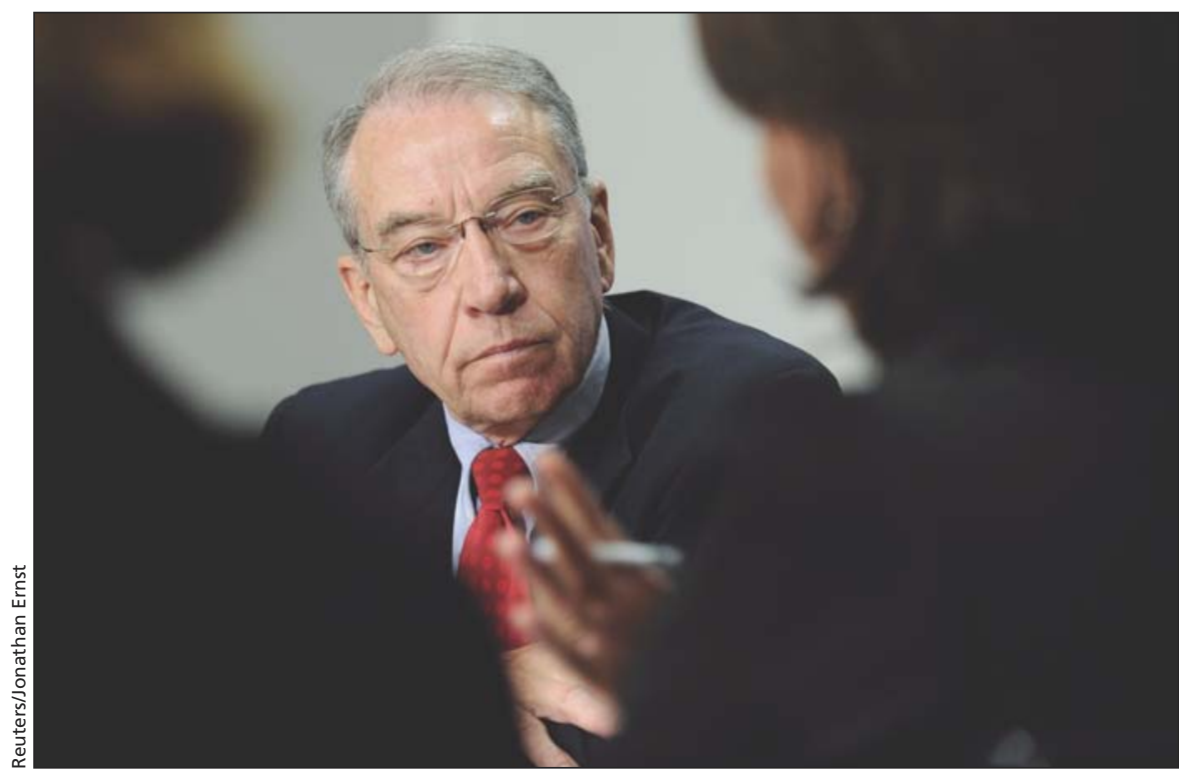

In introducing legislation to compel disclosure of pharmaceutical firm payments to doctors, United States Senator Charles Grassley (Republican-lowa) said "the best disinfectant of all: sunshine" needed to be applied to the shrouded world of industry handouts.

cians to use one device or another. We have a really astonishing number of physicians who are earning tens of thousands of dollars of outside income for essentially being part of the marketing activities of companies."

Officials estimate the drug industry alone spends almost US\$20 billion a year marketing to physicians in the form of gifts, lunches, junkets, speaking fees, drug samples and underwriting of education programs.

Lawmakers say the potential side effects of this largesse are significant: prescriptions chosen by a doctor based on industry influence instead of the patient's best interest; research skewed to benefit the sponsoring company; stresses on public health programs and private insurers from unnecessarily costly drugs instead of generics or other economical choices.

“Companies wouldn't be paying this money unless it had a direct effect on the prescriptions doctors write and the medical devices they use," Repub- lican Senator Charles Grassley of Iowa said when launching the legislative drive that was cosponsored by Democratic Senator Herb Kohl of Wisconsin. The legislation "sheds light on these hidden payments and obscured interests through the best disinfectant of all: sunshine."

Canadian practices seem destined to remain shrouded. The US law does not apply to American payments to foreign physicians, and Canadian regulators have not taken action of their own.

"There's nothing that any level of government has done to require physicians to disclose payments that they've received," says Dr. Joel Lexchin, who teaches health policy at York University in Toronto, Ontario.

"The reason is, there hasn't been a big enough scandal here about people getting money from the companies and doing some of the egregious things that we've seen in the States." He adds: "There's probably a lot going on that we don't know about." 
Grassley's Senate investigators put a trio of child psychiatry researchers at Harvard University in Boston, Massachusetts, under scrutiny for underreporting drug-company payments of more than US $\$ 1$ million each between 2000 and 2007. In another probe, a University of Wisconsin orthopedic surgeon was found to have received more than US\$19 million from a medical device company over four years while reporting to the university only that he got more than $\$ 20000$.

Although university researchers and many others face disclosure rules set by their institutions, financial relationships with industry have proved hard for employers to police. Now the uniform national registry makes the payers accountable - and the results public.

The law covers a wide range of industry payments, including these tallied by the Pew project: food, entertainment, gifts, travel, consulting fees, honoraria, research financing, education or conference support, stocks, stock options, ownership or investment interest, royalties, licences and charitable contributions.

Among the limited exemptions: rebates, discounts and loans of certain devices. Companies can delay disclosing payments related to clinical trials or product development for four years or until the product is approved. Drug and device samples are outside the public disclosure law but must be reported to the government.

The federal Health and Human Services Department will turn all the information into a searchable database showing the receiving physician's name and address, the value, date and nature of each payment or gift, and any product associated with the relationship. Companies can be fined up to US\$1 million a year for trying to hide transactions.
Some corporate disclosures have already begun, prompted by lawsuits, legal settlements or a wish to get out in front of the law. Pfizer, for example, reported paying out US\$35 million to some 4500 practitioners over six months last year.

Indeed, industry executives and their professional associations largely supported the legislation, although some winced as the requirements grew tighter during the debate. The law's success, Coukell says, will depend in large measure on whether companies try to exploit any loopholes.

"This is part of a culture change that's going on, where the profession is re-evaluating some of those financial ties," he says. "If they comply in good faith, then this is a fairly comprehensive bill." - Cal Woodward, Washington, DC

DOI:10.1503/cmaj.109-3263 